研究速報・Short Communication

\title{
アルミナと他の酸化物を同時添加した窒化ケイ素の 雾囲気加圧焼結
}

\author{
谷 英治・一ノ瀬弘道 ${ }^{*} \cdot$ 岸 和司・梅林正気・小林和夫

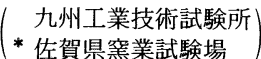 \\ (1983 年 12 月 5 日受付)
}

\section{Gas Pressure Sintering of $\mathrm{Si}_{3} \mathrm{~N}_{4}$ with Concurrent Addition of $\mathrm{Al}_{2} \mathrm{O}_{3}$ and Other Oxide}

\author{
Eiji TANI, Hiromichi ICHINOSE*, Kazushi KISHI, Seiki UMEBAYASHI \\ and Kazuo KOBAYASHI \\ $\left(\begin{array}{l}\text { Government Industrial Research Institute, Kyushu } \\ \text { Shuku-machi, Tosu-shi } 841 \\ \text { * The Saga Prefectural Ceramic Research Institute }\end{array}\right)$
}

[Received December 5, 1983]

Key-words : $\mathrm{Si}_{3} \mathrm{~N}_{4}$, Sintering, Gas pressure sintering, Additives

窒化ケイ素は難焼結性材料であり，0.1 MPa の窒素 雾囲気下では約 $1900^{\circ} \mathrm{C}$ で熱分解する ${ }^{1)}$.この熱分解を 抑えるには $2000^{\circ} \mathrm{C}$ で約 $3 \mathrm{MPa}$ の窒素圧 ${ }^{1)}$ が必要とされ ている．窒化ケイ素を $2000^{\circ} \mathrm{C}$ 以上の高温で焼成できれ ば, 焼結助剤の量を減少させたり, 高融点の液相を生じ る助剤を使用して高温強度の高い焼結体を得ることが期 待できる.

$\mathrm{MgO}^{21,3)}$ や $\mathrm{Y}_{2} \mathrm{O}_{3^{4}}{ }^{\prime, 5)}$ などの酸化物を焼結助剂として 用い $1450^{\circ} \sim 1950^{\circ} \mathrm{C}$ の温度, $1 \sim 2 \mathrm{MPa}$ の窒素ガス圧下 で焼成した窒化ケイ素焼結体は理論密度に近いものが得 られている. そして, 2 種類の酸化物を窒化ケイ素に同 時添加したものは, $\mathrm{Mitomo}^{2)}$ が $2.5 \mathrm{wt} \% \mathrm{Al}_{2} \mathrm{O}_{3}+2.5$ wt $\% \mathrm{Y}_{2} \mathrm{O}_{3}$ を添加し, $1800^{\circ} \mathrm{C} \cdot 1 \mathrm{MPa}$ の窒素圧下で 30 分間焼成して, $2.66 \mathrm{~g} / \mathrm{cm}^{3}$ の焼結体を得ている. また, Gazza ら ${ }^{6)}$ は, 10 wt \% $\mathrm{Y}_{3} \mathrm{Al}_{5} \mathrm{O}_{12}$ を添加して $1770^{\circ}$ 〜 $1780^{\circ} \mathrm{C} \cdot 2 \mathrm{MPa}$ の窒素圧下で 90 分間焼成して理論密度 に近い焼結体を得ている. 著者らは, $\mathrm{Al}_{2} \mathrm{O}_{3}$ に $\mathrm{Y}_{2} \mathrm{O}_{3}$, $\mathrm{La}_{2} \mathrm{O}_{3}$ 又は $\mathrm{CeO}_{2}$ を加えた焼結助剂を用い, $2000^{\circ} \mathrm{C} \cdot 4$ $\mathrm{MPa}$ までの窒化ケイ素の雾囲気加圧焼結を行ったので 報告する.

実験に用いた原料は, 東洋曹達工業社製 $\mathrm{Si}_{3} \mathrm{~N}_{4}$ ( TS-7, 平均粒度 $0.6 \mu \mathrm{m})$, 岩谷化学工業社製 $\mathrm{Al}_{2} \mathrm{O}_{3}$ ( $\mathrm{RA}-40$, 平均粒度 $0.83 \mu \mathrm{m}$ ), 信越化学社製 $\mathrm{Y}_{2} \mathrm{O}_{3}$ (平均粒度 3.5 $\pm 1 \mu \mathrm{m}) ，$ CERAC 社製 $\mathrm{La}_{2} \mathrm{O}_{3}$ (-325 メッシュ)，
$\mathrm{CERAC}$ 社製 $\mathrm{CeO}_{2}$ (ー325 メッシュ) である. $\mathrm{Si}_{3} \mathrm{~N}_{4}$ に， 5 wt $\% \mathrm{Al}_{2} \mathrm{O}_{3}+5$ wt $\% \mathrm{Y}_{2} \mathrm{O}_{3}, \quad 5$ wt $\% \mathrm{Al}_{2} \mathrm{O}_{3}+5$ wt \% $\mathrm{La}_{2} \mathrm{O}_{3}$, 及び, 5 wt \% $\mathrm{Al}_{2} \mathrm{O}_{3}+5$ wt $\% \mathrm{CeO}_{2}$ となるよう に添加し, $\mathrm{Si}_{3} \mathrm{~N}_{4}$ ボールでエタノールを用いて 2 日間 ボールミル混合後, 吸引沪過し, 真空乾燥した.この混 合試料約 $11 \mathrm{~g}$ を $30 \times 30 \mathrm{~mm}$ の金型で $98 \mathrm{MPa}$ の一軸加 圧成形を行い, 更に $490 \mathrm{MPa}$ でラバープレスして密度 約 $1.7 \mathrm{~g} / \mathrm{cm}^{3}$ の成形体を得た。

$\mathrm{BN}$ るつぼの中に下から順に, $\mathrm{Al}_{2} \mathrm{O}_{3}+\mathrm{Y}_{2} \mathrm{O}_{3}, \mathrm{Al}_{2} \mathrm{O}_{3}+$ $\mathrm{CeO}_{2}, \mathrm{Al}_{2} \mathrm{O}_{3}+\mathrm{La}_{2} \mathrm{O}_{3}$ を添加した成形体を入れて, 各々 の成形体を $\mathrm{BN}$ の圧粉体で分離した。この $\mathrm{BN}$ るつぼ を雾囲気加圧焼成炉に入れ, $1800^{\circ} \mathrm{C} \cdot 2 \mathrm{MPa}, 1900^{\circ} \mathrm{C}$ ・ $3 \mathrm{MPa}, 2000^{\circ} \mathrm{C} \cdot 4 \mathrm{MPa}$ の温度・窒素圧条件下で雾囲 気加圧焼成した. 室素ガスは $1100^{\circ} \mathrm{C}$ で所定の圧力に達 するように初圧を設定した。加熱は $1100^{\circ} \mathrm{C}$ までは約 50 分間で昇温後, $10^{\circ} \mathrm{C} / \mathrm{min}$ で昇温し, 60 分間保持後, 炬 冷した。焼成した試料は重量を測り，表面相をX線回 折法で同定し, 水中置換法で密度の測定を行った.

焼結体の密度及び重量変化を図 1 に示す。焼結体の重 量は温度の上昇に伴い,わずかに減少する傾向があるが, $2000^{\circ} \mathrm{C} ・ 4 \mathrm{MPa}$ の条件下でも $2 \%$ 以下であった. 焼結 体の密度は $1800^{\circ} \mathrm{C} \cdot 2 \mathrm{MPa}$ で既に密度 $3.0 \mathrm{~g} / \mathrm{cm}^{3}$ 前後 のものが得られた. $\mathrm{Al}_{2} \mathrm{O}_{3}+\mathrm{Y}_{2} \mathrm{O}_{3}$ を添加したものは, $2000^{\circ} \mathrm{C}$ まで温度を上げてもほとんど密度は増加しな 


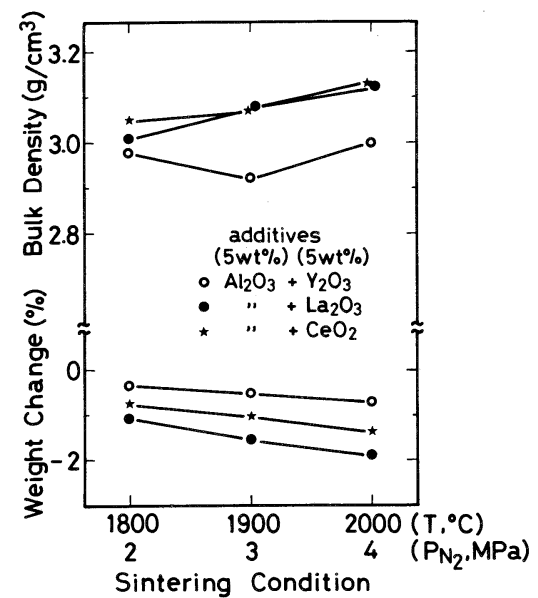

Fig.1. Effect of sintering condition on bulk density and weight change of the gas pressure sintered $\mathrm{Si}_{3} \mathrm{~N}_{4}$.

かったが，他のものは温度の上昇に伴い，わずかではあ るが密度の増加が認められた。 $\mathrm{Al}_{2} \mathrm{O}_{3}+\mathrm{CeO}_{2}$ を添力し たものは, $2000^{\circ} \mathrm{C} ・ 4 \mathrm{MPa}$ で最高の密度 $3.13 \mathrm{~g} / \mathrm{cm}^{3}$ を 示した.
$\mathrm{Al}_{2} \mathrm{O}_{3}+\mathrm{Y}_{2} \mathrm{O}_{3}, \mathrm{Al}_{2} \mathrm{O}_{3}+\mathrm{CeO}_{2}$ を添加した焼結体の表面 相は, 上下面ともすべて $\beta-\mathrm{Si}_{3} \mathrm{~N}_{4}$ のみであった. $\mathrm{Al}_{2} \mathrm{O}_{3}$ $+\mathrm{La}_{2} \mathrm{O}_{3}$ を添加した焼結体の表面相は, 下面は $\beta-\mathrm{Si}_{3} \mathrm{~N}_{4}$ のみであり, 上面は $\beta-\mathrm{Si}_{3} \mathrm{~N}_{4}, \mathrm{BN}$ 及び末同定相を生成 していた。しかし, 上面を研削した後では $\beta-\mathrm{Si}_{3} \mathrm{~N}_{4}$ のみ であった.

本実験から, $4 \mathrm{MPa}$ の窒素ガス圧で酸化物の助剂を 添加した $\mathrm{Si}_{3} \mathrm{~N}_{4}$ の熱分解を $2000^{\circ} \mathrm{C}$ においてもかなり抑 えることができ, 重量減少のほとんどない高密度の焼結 体を得られることが明らかになった。

謝 辞 本研究遂行に当たり熱心に協力された川原ヒサヨ 氏に感謝致します。

$$
\text { 文献 }
$$

1) C. Greskovich and S. Prochazka, J. Am. Ceram. Soc. , 64, C-96-97 (1981).

2) M. Mitomo, J. Mater. Sci., 11, 1103-07 (1976).

3）三友 護, 大島忠平, 堤 正幸, 畺協, 84, 356-60 (1976).

4) F.S. Galasso and R.D. Veltri, Am. Ceram. Soc. Bull., 58, 793-94 (1979).

5) F.S. Galasso and R. D. Veltri, J. Am. Ceram. Soc., 64, C-15-16 (1981).

6) G.E. Gazza, R. N. Katz and H.F. Priest, J. Am. Ceram. Soc., 64, C-161-162 (1981). 